\section{perifèria}

Número 15, desembre 2011

www.periferia.name

\title{
Tèrbola realitat: emergència a l'espai públic
}

\author{
Erika Cabrera, Marta Calvo i Mar Pujol ${ }^{1}$ \\ Universitat Autònoma de Barcelona
}

\begin{abstract}
Uribe Vilarrodona, Joan. (2011) El costat fosc. Diari de camp d'un cotxe patrulla dels Mossos d'Esquadra. Barcelona: Cossetània Edicions.
\end{abstract}

Pa i circ... Que s'hagi trobat fórmules socialment controlades i menys violentes de "donar circ" a les masses, (...) no pot anul.lar la societat en estat pur, l'energia nascuda del moment en un grup social més enllà de cadascun dels seus membres, l'excitació filla de l'emergència. [...] El policia ho sap: sap que el seu veí, la seva mare, els seus fills $i$ ell mateix, són això, societat en estat pur (...). ${ }^{2}$

Carrer, espai públic, escenari de vida i mort, d'emergència, de crisi; l'estat pur, la substància que defineix la continua reestructuració ${ }^{3}$ de la urbs. Precisament, aquest és el "costat fosc" que Joan Uribe pretén mostrar al seu treball: moments, instants que trenquen la suposada calma que s'inscriu dins la quotidianitat, dins la normalitat de la vida social. I, per fer-ho, s'endinsa en el món dels Mossos d'Esquadra, com un intent de mostrar aquesta "cara oculta" de la ciutat, aquella

1 Enviar correspondència a: Erika Cabrera erika.cabrera@e-campus.uab.cat; Marta Calvo martaraxia@gmail.com; Mar Pujol mapumo21@gmail.com.

2 Uribe Vilarrodona, Joan. (2011) El costat fosc. Diari de camp d'un cotxe patrulla dels Mossos d'Esquadra. Barcelona: Cossetània Edicions. p.60.

3 Com bé diu Uribe a la seva tesi, s'ha de conceptualitzar l'existència col-lectiva, en el marc d'unes relacions socials efímeres, com una realitat que no està per si estructurada, sinó que està en continua estructuració, sempre estructurant-se. (2007:22) 


\section{perifèria}

Número 15, desembre 2011

www.periferia.name

realitat amagada que la policia, de la mateixa manera que la resta de "treballadors del carrer", en coneix la fórmula per desemmascarar.

L'obra, diari de camp que constitueix la base etnogràfica de la seva tesi doctoral Interacció $i$ emergència. L'espai públic com a escenari d'esdeveniments ${ }^{4}$, mostra, gràcies a l'observació participant que l'autor va dur a terme amb diferents patrulles de Mossos d'Esquadra en els municipis de Lloret de Mar i I'Hospitalet de Llobregat, quina és la realitat que es viu dins I'espai públic urbà, constantment canviant i emergent. Com bé indica a la seva tesi, Uribe es va centrar en la recerca de fenòmens que s'adeqüessin a la noció d'emergència en la seva doble vessant: per una banda, seguint la seva etimologia, com allò que "surt de dins", que apareix, es revela i es fa visible; per l'altra, com a acció que desmenteix la "normalitat" de la quotidianitat creant una situació d'alarma vers un perill aparentment visible (2007:20). És, doncs, l'emergència l'objecte emfatitzat per l'autor, on l'espai públic és entès com una comarca de relacions inestables, canviant i improvisada, sent la ciutat escenari d'esdeveniments.

El text es divideix en dues parts: la primera fa referència al treball de camp dut a terme a Lloret de Mar durant I'agost de 2002; la segona, al juliol de 2004, narra els torns realitzats a I'Hospitalet de Llobregat. Cada capítol exposa una jornada de patrullatge on s'explica, de manera detallada i minuciosa, com si d'una novel·la negra es tractés, els fets que es van produint de manera improvisada, en un ambient en crisi, inestable, reflectint la fragilitat de l'ordre social, així com la debilitat de les institucions públiques i socials que "controlen", tot vetllant per la seguretat ciutadana, I'ordre dins del "desordre públic", caracteritzat per l'espontaneïtat i la improvisació.

De fet, Joan Uribe, doctor en Antropologia Social per la Universitat de Barcelona i especialitzat en Antropologia de I'Espai i el Territori, ha treballat en diversos àmbits

\footnotetext{
${ }^{4}$ Dirigida per Manuel Delgado, la tesi va ser publicada al 2007 a partir del treball de camp realitzat a Barcelona (2001), Lloret de Mar (2002) i a l'Hospitalet de Llobregat (2004), així com de l'experiència de l'autor com a Mosso d'Esquadra en diferents àmbits de la criminalitat.
} 


\section{perifèria}

Número 15, desembre 2011

www.periferia.name

de la criminalitat, concretament en la investigació del crim organitzat. Aquesta doble perspectiva d'investigador social i de Mosso d'Esquadra queda reflectida al seu diari de camp que, alhora que actua com a punt clau per descobrir els estigmes als que policia i població estan sotmesos, sovint porta a una confusió de rols, en tant que els "límits" entre observador i observat es difuminen esbiaixant, en certa mida, la realitat. Amb tot, però, aconsegueix arribar a aquell costat fosc de la vida de la ciutat -que no es redueix a actuacions durant la nit o a espais marginals de difícil accés- sota la mirada del què significa i és ser policia. Perquè els policies, com a "treballadors del carrer", de la mateixa manera que bombers, conductors d'ambulàncies, personal de neteja i altres sectors de l'àmbit dels serveis d'emergència, poden veure tot allò que succeeix vertaderament dins els espais públics de la urbs i que, sovint, la nostra mirada omet, potser perquè no entra dins de la "normalitat" o del què entenem per "normal":

És un reconeixement entre aquells que estan al carrer $i$ saben, tots ells, que poden trobar-se amb qualsevol circumstància sorprenent $i$ gens desitjable. [...] És un reconeixement mutu com a especialistes de l'alarma i de la seguretat amb formes d'actuació a vegades semblants (...) i prerrogatives també semblants (...) (2011:92-93).

Així, doncs, els policies, agents dedicats a la seguretat ciutadana, sempre determinats per l'eventual alteració de l'entorn, són especialistes de la gestió del moment, d'allò inesperat, del més ampli ventall de contingències que necessiten un tractament urgent $i$ alhora curós, ràpid, correcte $i$ amb un mínim marge d'error. (2011:22) En aquest sentit, l'espai públic deixa de ser únicament un espai de pas ${ }^{5}$ per transformar-se en un escenari constantment canviant i emergent, on es reflecteix de forma "natural" l'estat pur de la societat: aquesta constància i inconstància d'esdeveniments que, sovint traspassant les fronteres de la legalitat, es circumscriuen dins la marxa vital de la ciutat.

\footnotetext{
${ }^{5}$ Fem ús del concepte "espai de pas" per definir l'àmbit públic com un espai que, sent de tots i alhora de ningú, es presenta com una realitat distorsionada: les persones ens movem constantment en els espais públics, en una contínua circulació de vides aparentment independents, sense parar atenció, sense observar ni analitzar la realitat, la pura, la vertaderament "normal".
} 


\section{perifèria}

Número 15, desembre 2011

www.periferia.name

Aquest reconeixement de les "forces de I'ordre públic" com a especialistes de la gestió del moment i defensors de la seguretat ciutadana però, sembla no ser un reconeixement unànime. Al contrari, de la mateixa manera que lladres, estafadors, delinqüents i assassins, el cos policial està subjecte a una sèrie d'estigmatitzacions, sovint contràries, que afecten en gran mesura el seu treball ja que, a banda de patir l'estigma, el transporten, marcant -tacant- el lloc on són i la gent amb qui parlen. En aquest sentit, la presència policial es presenta com a "criminalitzadora" d'espais, associada a problemes i percebuda com a font de problemes. Por, inseguretat, incomoditat, emergència, perill... Són només algunes de les sensacions que provoquen la presència dels cossos policials, aquells que, aparentment, haurien d'aportar tranquil·litat, seguretat davant d'un perill extern.

Uribe argumenta, però, que quan la situació es presenta com a greu, la reacció davant la policia divergeix d'aquesta "incomoditat ciutadana": la "taca policial" es presenta com a necessària i immediata, ja que es considera que els agents poden i han de solucionar qualsevol tipus de conflicte o problemàtica sorgida al carrer, sovint confonent emergència amb urgència. Aquesta necessitat per part de la població a que la reacció i actuació dels agents sigui instantània ve donada per la pressuposició que l'únic responsable de la gestió dels problemes és el cos policial:

a la mínima, les persones no només refusen l'obligació de ser solidaris $i$ corresponsables en l'auxili d'altres, sinó que sovint defugen la seva responsabilitat quan veuen un policia a prop. (2011:53)

És evident que tots ens movem sota la premissa de que tot allò que atempti contra la nostra integritat física i personal ha de ser evitat i rebutjat de tal forma que, defensats per les lleis existents, busquem formes de justícia que protegeixin la nostra identitat com a ciutadans. Però, com ho fem per dur a terme aquestes "justícies" i quins són els límits legals i morals entre elles? Uribe fa referència a la justícia informal i la justícia formal. La primera és aquella on les persones actuen davant un succés per la "seva pròpia mà", és a dir, imparteixen la seva pròpia justícia en autodefensa, sovint sobrepassant les fronteres legals establertes pels estats. La segona, en canvi, es tracta d'una justícia institucionalitzada, que ve donada pels membres amb possessió de l'autoritat atorgada pel propi estat, és a 


\section{perifèria}

Número 15, desembre 2011

www.periferia.name

dir, la policia: les forces de l'ordre públic. Però, què entenem per justícia? És realment la justícia formal -legal- sempre la més "eficaç" i "justa"? L'autor reflexiona sobre aquesta qüestió, un tema francament difícil i que sembla no tenir una resposta gaire axiomàtica. Menys encara quan el mateix concepte de "justícia" pot tenir diverses interpretacions:

La justícia informal ha estat efectiva, perquè ha neutralitzat l'agressor, però, aparentment, $i$ com passa sovint quan s'exerceix l'anomenada "justícia popular", ha acabat causant més mal que l'originada pel transgressor, és a dir, no ha estat proporcional. [...] La justícia formal es legal, però no sempre justa. La justícia informal, malauradament, pot ser més injusta encara. (2011:116-117).

Tornant a l'espai públic, entès ara com el carrer en la seva accepció més àmplia (places, travessies, carrerons... Tots aquells racons de la ciutat que són presents en totes i cada una de les emergències) sembla adquirir també una "actitud" davant aquestes situacions de crisi així com davant les actuacions policials. D'aquesta manera, sembla esdevenir-se una "entrega" del carrer al servei d'emergència: l'espai pateix una pausa, es transforma en un espai atemporal, congelat, on tot allò que transcorre "fora" d'aquest espai detingut, segueix en el seu ritme temporal habitual. En aquest sentit, l'espai, alhora que pateix una mena de sacralització, actua com a testimoni mut del que ha succeït, com bé diu l'autor:

és un punt neutre, tan aparentment asèptic com la resta d'espai públic que l'envolta, tan transitat, tan quotidià com qualsevol altre punt. Ningú dels qui passen pel lloc poden imaginar-se'l ple de sang, com a escenari d'una tragèdia. (2011:145)

Uribe, doncs, sembla contextualitzar les emergències dins la quotidianitat, dins la realitat, de la "normalitat" de la vida social. Aquesta posició, que divergeix en gran mida de la "realitat" representada per la societat, ens sembla, potser, un dels encerts de l'autor en la seva investigació.

Certament, realitzar un treball de camp on l'objecte d'estudi sigui l'observació d'emergències dins la ciutat, no és una tasca gens fàcil. Menys encara si tenim en compte que aquest espai públic es presenta múltiple i simultani: un escenari 


\section{perifèria}

Número 15, desembre 2011

www.periferia.name

d'esdeveniments on els ciutadans -tots aquells individus que conformen una societat- són actors representant tots els desenllaços possibles (2007:10).

En aquest sentit, es tracta d'un estudi innovador $\mathrm{i}$ amb un gran interès social si tenim en compte les actuals polèmiques que giren entorn els cossos policials i, més concretament, entorn la tasca realitzada pels Mossos d'Esquadra a Catalunya. De fet, Uribe fa referència a aquestes polèmiques al seu diari de camp esmentant la carta d'un lector, a l'edició digital d'El Periódico, on es qüestiona el treball dels Mossos. El lector es posiciona en contra de la violència policial tot denunciant la falta d'humanitat que els policies, "marginals uniformats", adopten vers els ciutadans. Davant d'aquest adjectiu qualificatiu -amb unes connotacions clarament negatives- Uribe respon que, de fet, per a molts, és el que som: marginats d'uniforme, cometent l'error de limitar l'estigma als efectes que porta dur un uniforme i ignorant la crítica real desenvolupada pel lector, més a prop de qüestionar el seu treball com a funcionaris públics i no la seva vestimenta (2011:80).

Pot semblar, des d'aquest punt de vista, que el treball únicament contempli una de les perspectives -la dels cossos policials- obviant altres punts de vista que esdevenen crucials per a l'anàlisi del "fet urbà". Amb tot, però, no es tracta de fer aquí una anàlisi de les conclusions arribades per Uribe a partir de la seva investigació. Certament, tot i que l'autor realitza algunes reflexions durant les seves observacions, a l'obra no hi consta cap anàlisi crítica dels fets observats. De fet, les conclusions a les que arriba apareixen únicament a la seva tesi, fet que provoca que per poder obtenir una àmplia comprensió del seu treball, sigui necessària la seva lectura. En aquest sentit, l'obra es presenta com un relat de distintes situacions ocorregudes a l'espai públic, oferint al lector la llibertat d'interpretar-les amb tota sobirania.

Davant d'això, ens limitarem a fer una valoració de la metodologia emprada per Uribe i que es reflecteix en les pàgines que conformen el seu diari de camp. En aquest sentit, l'obra sembla assolir els objectius proposats per l'autor que, fent ús de I'observació participant, s'ha endinsat en la "realitat amagada" que s'adverteix dins l'emergència. Realitzant un comentari crític, però, observem que si bé es 


\section{perifèria}

Número 15, desembre 2011

www.periferia.name

notòria la capacitat d'Uribe per descriure tot un seguit de situacions crítiques dins les vicissituds que defineixen la constant estructuració de la urbs, sovint I'observació es "massa participant" reduint l'estudi de l'Altre -on l'autoqüestionament es presenta com a requisit innegociable- a un estudi de la quotidianitat dels cossos policials catalans com a testimonis primordials per a la reflexió sobre "el costat fosc" que es registra dins l'existència urbana i social.

És a partir de l'observació de les emergències, enteses com a traumes, crisis dins d'un ordre racional establert, quan hom s'adona de la precarietat i la inestabilitat que caracteritza I'ordre social. En efecte, aquesta incontestabilitat de l'emergència pot trencar aquest ordre, constatant així, la fragilitat del pacte social. És evident que l'emergència, el costat fosc que s'inscriu dins la quotidianitat de la urbs, no és quelcom abstracte que emergeix del no res com si d'un ens indeterminat i surrealista es tractés. Ans, al contrari, està implícita en la essència mateixa de la vida de la comunitat, subjacent a tot vincle social que uneix les multituds i estructura la seva convivència en aquesta dimensió sigil·losa i misteriosa de la vida social. El costat fosc és dins de cada un de nosaltres; és tan real, com reals són els nostres actes, accions i moviments, tot allò que conforma el fet urbà i la seva realitat:

En canvi, jo crec que si que té a veure amb la realitat. Es més, sospito que aquesta és l'autèntica realitat i que l'altra, la "normal", és la que és només un miratge. (2011:187)

\section{Bibliografia}

Uribe Vilarrodona, Joan (2007) Interacció i emergència. L'espai públic com a escenari d'esdeveniments. (Tesi Doctoral - Universitat de Barcelona) [En línea] Disponible en: http://tdx.cat/bitstream/handle/10803/719/JUV TESI.pdf?sequence $\equiv 1 \& \mathrm{fb}$ source $=$ message $\quad$ [Última consulta: $26 / 11 / 2011 ; 20.30 \mathrm{~h}$ ] 